\title{
EFFECTS OF FADAMA III PROJECT ON RURAL RICE FARMERS IN YOLA -NORTH LOCAL GOVERNMENT AREA OF ADAMAWA STATE, NIGERIA
}

\author{
B. A Shelleng ${ }^{1}$ and B. Tabitha ${ }^{1}$ 四 \\ ${ }^{1}$ Department of Agricultural Economics and Extension, Adamawa State University, Mubi, Adamawa State. Nigeria
}
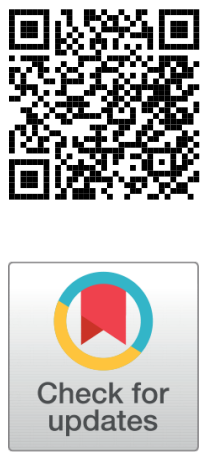

Received 23 March 2021

Accepted 6 April 2021

Published 30 April 2021

Corresponding Author

B. A Shelleng, balaabubakar76@y

ahoo.com

DOI $10.29121 /$

granthaalayah.v9.i4.2021.3823

Funding: This research received no specific grant from any funding agency in the public, commercial, or not-for-profit sectors.

Copyright: (C) 2021 The Author(s). This is an open access article distributed under the terms of the Creative Commons Attribution License, which permits unrestricted use, distribution, and reproduction in any medium, provided the original author and source are credited.

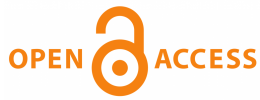

\section{ABSTRACT}

The study assessed the effects of Fadama lll on rural rice farmers in Yola-North LGA of Adamawa State, Nigeria. The objectives are to; described the socioeconomic characteristics of the respondents, Estimate the cost and returns of Fadama and non-Fadama participants, to assess the change in output and to assess the change in income among the respondents. One hundred and twenty four (124) respondents were selected from beneficiaries and non-beneficiaries of the project through multi stage and purposive random sampling. Structured questionnaire were used to obtained data on the Socio-economic characteristics, Cost and Returns, Change in output and Change in income. The data were analysed using Descriptive and inferential statistics. The findings reveals that majority of the respondents were males (71.4\%) and married (69.6).These categories of respondents are in their productive ages (30 - 39 and 40 - 49) capable of engaging in farming activities and they account for $64 \%$ whom are the majority. Revenue generated by the beneficiaries is higher than that of the non-beneficiaries as revealed by the Gross margin analysis, likewise the T-test showed the mean Income of the beneficiaries was higher compared to that of the non-beneficiaries even though the difference was not significant at $\mathrm{p}=0.05$ .Despite the fact that the project had made little impact on the living conditions of the beneficiaries, it is recommended that it should be continue in order to ensure sustained income and revenue generation.

Keywords: Effects, Fadama III, Project, Rice, Farmers

\section{INTRODUCTION}

Self-sufficiency in food production based only in rain fed agriculture is difficult to achieve. This is particularly true for Nigeria. So, for self-sufficiency in food Production, there is need to extend the farming season beyond the rainy season through irrigated agriculture (Anambra State Agricultural Development Project - ASADEP, 
2000). To ensure that this laudable objective of self-sufficiency in food production is achieved. The Federal Government approved the implementation of the national Fadama development project (Obiechina \& B, 2000). The implementation of Fadama project ensures that agricultural production is carried on during both Seasons. Fadama is a Hausa word regarded as the low-lying flood-prone lands found in the plains of rivers. Fadama areas are composed of deposited sediments and contain exploitable aquifers (water tables). It involves preparation of low-lying areas and flood plains for crops, agroforestry and livestock production. The National Fadama Facility (NFF) was established under the NFDP loan No. 3541 UNI to assist Fadama development in the states that met the pre-determined eligibility criteria (Federal Agricultural Coordinating Unit - FACU 1995). The NFDP was approved for funding on March 26, 1992 for a loan of US \$ 67.5Million. It was to build on the achievements of some of the Northern ADPs in developing small-scale irrigation through extraction of shallow ground water, Using low-cost petrol-driven pumps. It was intended to raise farmers' incomes and contribute to food security and poverty alleviation (World Bank 1990). The loan closed on December 1999. The initial beneficiary states included Bauchi, Kano, Sokoto, Jigawa and Kebbi. The National Fadama III Development Project (NFDP III) is a follow up project on the success of the National Fadama II Development Project. The National Fadama III Development Project was implemented in all the 36 states of the Federation including the Federal Capital Territory (F.C.T) Abuja. It is funded by the International Development Agency (IDA). The broad objective of NFDP III is poverty reduction through increase in the income of the beneficiaries on sustainable basis. The specific objectives of the project were to reduce rural poverty, ensure food security and contribute to the achievement of the key Millennium Development Goal of food security (Oriola, 2009). NFDP III relies on the facilitation of demand-driven investments and the empowerment of local community groups to improve farm and non-farm productivity and land quality.

In Nigeria, many efforts have been made by successive government in order to improve living standard and quality of life of their citizens. These efforts are through programs such as; River Basin and Rural Development Authorities (RBDAs), Operation Feed the Nation (OFN), Green Revolution, Better Life Programme (BLP), National Agricultural Land Development Authority (NALDA), Agricultural Credit Guarantee Scheme Fund (ACGSF), National Accelerated Food Production Programme (NAFPP), National Programme on Food Security (NPFS), National Agricultural Support Programme (NASP), Agricultural Development Project (ADP), Nigerian Agriculture and Cooperative Bank (NACB) and so much more were established by the federal government. Some of which are still on going and others has gone morbid. Despite all these programs and projects established by the government, poverty still persisted. The establishment of Fadama II projects in 2004 recorded some success but covers only few states. The success recorded thus prompted the government to continue with Fadama III which covers all states of the nation. After the establishment of Fadama III, there are still traces of poverty among farmers in Yola North L.G.A. of Adamawa 
state. As a result of these, this study will like to assess the effects of the program on rice farmers in the study area through the following objectives-

1. Describe the socio-economic characteristics of the respondents;

2. Estimate the cost and returns of Fadama and non-Fadama participants;

3. To assess the change in output among the respondents and

4. To assess the change in income among the respondents

\section{METHODOLOGY}

Yola North is a local government in Adamawa state with administrative headquarters in the city of Jimeta. It forms a federal constituency alongside Girei and Yola South government areas. The city is situated on altitude $186 \mathrm{~m}$, located on the Benue River. Yola North local government area has an area of $113 \mathrm{~km} 2$, making it the smallest local government area by landmass in Adamawa State, with a population of 199674 (NPC, 2010). Yola North's geographical coordinates are 9017'0" North, 12028'0" East. There are eleven wards in Yola North local government area namely; Ajiya, Alkalawa, Doubeli, Gwadabawa, Jambutu, Karewa, Limawa, Luggere, Nassarawo, Rumde and Yelwa.

The wet season is hot with clouds covering the sky and the dry season is hot and partly cloudy. It has the tropical wet climate also called tropical hinterland climate. Locally the climate is called High Plateau climate. The climate fits into Aw of Koppen classification of climate. The precipitation varies $211 \mathrm{~mm}$ between the driest month (January) and the wettest month (August). With an average of 32.1oC, April is the warmest month. December, the coldest month with temperature averaging $25.90 \mathrm{C}$. Rainfall is between $900-1200 \mathrm{~mm}$ per annum, with high relative humidity. Dry season lasts for a period of six months (November-April) and the wet season spans from May to October (Adebayo, 1999).

The dominant type of soil is the laterite soil. The soils are heavily leached due to rainfall. Major crops grown in the area includes rice, maize, sorghum, millet, soya beans and cassava, with maize as the most important food crop grown and consumed in the area.

\subsection{SAMPLING TECHNIQUE}

The population for this study comprises of registered Fadama III rice farmers and Non-registered rice farmers in Yola North. A multi stage and purposive random Sampling technique was employed for the study. In stage I, two area councils and a physically challenged Fadama Community observed with high practice of irrigation farming was selected namely: Rumde having six (6) groups each consisting of fifteen (15) members making a total of ninety (90) and Limawa having Five (5) groups each consisting fifteen (15) members making a total of seventy-five (75). The physically challenged community having four (4) groups each consisting of ten (10) mem- 
bers making a total of forty (40). Stage II, Fadama III user group registered members was selected from each area council mentioned above respectively. Stage III, 30\% of the population sample of the registered Fadama User Group members for each area council was used as sample size for the study. Respondents were selected proportionate to the numbers of Fadama III user groups in the area councils to make up for total sample size of sixty-two (62) respondents. Similar procedure was used to select sixty-two (62) non-beneficiaries with comparable socio-economic characteristics. In all, a total sample of one hundred and twenty-four (124) farmers was issued for this study but only one hundred and fifteen (115) were valid, nine were invalid. So, a total of one hundred and fifteen (115) was used for the study.

\section{DATA ANALYSIS}

Both descriptive and inferential statistics was used. Descriptive statistics involved; Frequency counts, mean, average and percentages was used to achieve objective (i). Gross margin was used to achieve objective (ii) and T-test was employed to compare the means from before and after the project between beneficiaries and Nonbeneficiaries of the project to achieve objectives (iii and IV).

Gross margin is stated as

$\mathrm{GM}=\mathrm{TR}-\mathrm{TVC}$

Where;

$\mathrm{GM}=$ Gross margin $(\mathrm{N})$

TVC $=$ Total variable cost

$\mathrm{TR}=$ Total Revenue

Profit were given by

$\mathrm{p}=\mathrm{GM}-\mathrm{TFC}$

Where

$\mathrm{p}=$ Profit/ Net Farm Income

$\mathrm{GM}=$ Gross margin

$\mathrm{TFC}=$ Total Fixed cost

The general formula for the T-test is given as:

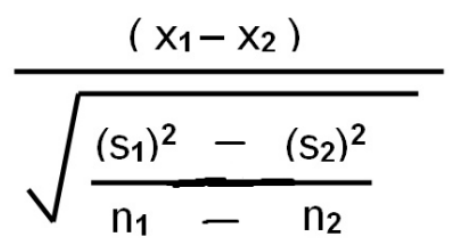

Where $\mathrm{T}=\mathrm{t}$-value

$\mathrm{X} 1$ = the mean sample of beneficiary before the project

$\mathrm{X} 2=$ the mean sample of beneficiaries after the project

S12 = sample standard deviation for the beneficiary before 
the project

S22 = sample standard deviation for the beneficiary after the

project

n1 = sample size of beneficiary before the project

$\mathrm{n} 2$ = sample size of beneficiary after the project

\section{RESULTS AND DISCUSSION}

Result of the findings of the effects of Fadama III project on rural rice farmers in Yola north Local Government Area, Adamawa State are discussed here. The data were obtained from Fadama III Beneficiaries and non-beneficiaries, on socio-economic characteristics, cost and returns of rice

\subsection{PRODUCTION, CHANGE IN OUTPUT AND CHANGE IN INCOME}

\begin{tabular}{|c|c|c|c|c|}
\hline & Beneficiaries & & $\begin{array}{c}\text { Non - } \\
\text { Beneficiaries }\end{array}$ & \\
\hline Variables & Frequency & Percentage & Frequency & Percentage \\
\hline \multicolumn{5}{|l|}{ Sex } \\
\hline Male & 39 & 66.1 & 40 & 71.4 \\
\hline Female & 20 & 33.9 & 16 & 28.6 \\
\hline \multicolumn{5}{|l|}{ Age } \\
\hline Less than 30 & 6 & 10.2 & 9 & 16.1 \\
\hline $30-39$ & 12 & 20.3 & 13 & 16.1 \\
\hline $40-49$ & 22 & 37.3 & 17 & 30.4 \\
\hline $50-59$ & 16 & 37.1 & 13 & 23.2 \\
\hline 60 and above & 3 & 5.1 & 4 & 7.1 \\
\hline
\end{tabular}

Source: field work, 2019.

Sex - The results as presented in table 1 shows that majority (66.1\%) of the beneficiaries were male, while $33.9 \%$ were Female. About $71.4 \%$ of the non-beneficiaries were male while $28.6 \%$ were females. This implies that the project allowed both the participation of male and female. This is consistent with the findings of Akangbe et al. (2012) in his study. The assessment of the effect of Fadama II on Livelihood of Farmers in Orire Local Government Area of Oyo State which reveals that majority of the respondents were male. 4.1.2 Age The respondents were also asked to indicate their ages, and as the study reveals in table $1,37.3 \%$ of the beneficiaries were between the ages of $40-49$ years. About $27.1 \%$ were within the age of $50-59$ years. This was followed by $20.3 \%$ that were within the age of $30-39$ years, $10.2 \%$ that were of less than 30 years and $5.1 \%$ were above 60 years. On the other hand, 30.4\% of the non-beneficiaries where within the age of $40-49$ followed by $23.2 \%$ that were within $30-39,16.1 \%$ were less than 30 and $7.1 \%$ were above 60 . This result agrees 
with the findings of Iwala (2014), that men and women of active and productive age are still prepondence in rural areas of Ondo state.

Table 2 Marital status, level of education, and household size

\begin{tabular}{|c|c|c|c|c|}
\hline \multirow[b]{2}{*}{ Variables } & \multicolumn{2}{|c|}{ Beneficiaries } & \multicolumn{2}{|c|}{ Non - Beneficiaries } \\
\hline & Frequency & Percentage & Frequency & Percentage \\
\hline \multicolumn{5}{|l|}{$\begin{array}{l}\text { Marital } \\
\text { status }\end{array}$} \\
\hline Single & 4 & 6.8 & 8 & 16.1 \\
\hline Married & 42 & 71.2 & 39 & 69.6 \\
\hline Widowed & 7 & 11.9 & 5 & 10.7 \\
\hline Divorced & 6 & 10.2 & 4 & 3.6 \\
\hline \multicolumn{5}{|l|}{$\begin{array}{c}\text { Level of } \\
\text { education }\end{array}$} \\
\hline $\begin{array}{l}\text { Non formal } \\
\text { Education }\end{array}$ & 14 & 23.7 & 3 & 3.4 \\
\hline $\begin{array}{l}\text { Primary } \\
\text { education }\end{array}$ & 6 & 10.2 & 10 & 17.9 \\
\hline $\begin{array}{l}\text { Secondary } \\
\text { education }\end{array}$ & 30 & 50.8 & 33 & 58.9 \\
\hline $\begin{array}{c}\text { Adult } \\
\text { education }\end{array}$ & 9 & 15.3 & 10 & 16.1 \\
\hline \multicolumn{5}{|l|}{$\begin{array}{l}\text { Household } \\
\text { size }\end{array}$} \\
\hline $1-5$ & 12 & 20.3 & 14 & 25 \\
\hline $6-10$ & 26 & 44.1 & 24 & 42.9 \\
\hline $11-16$ & 16 & 27.1 & 11 & 19.6 \\
\hline $\begin{array}{l}17 \text { and } \\
\text { above }\end{array}$ & 5 & 8.5 & 7 & 12.5 \\
\hline
\end{tabular}

Source: field work, 2019.

Marital status- As the result also shows in table 2, majority of the beneficiaries $(71.2 \%)$ and $69.6 \%$ of the non-beneficiaries were married. Others were $11.9 \%$ and $10.7 \%$ widowed, $10.2 \%$ and $3.6 \%$ divorced and $6.8 \%$ and $16.1 \%$ singles for the beneficiaries and non-beneficiaries respectively. This implies that the beneficiaries have partners who could encourage them to participate in such programs to increase their income. This is in line with the result of Balogun et al., (2012). That

the majority of the respondents were married and this implies that there is likely to be more family labour available for farm work. 4.1.4 Level of Education

Majority of the beneficiaries (50.8\%) had secondary education, $23.7 \%$ had no formal education, $10.2 \%$ had completed primary school and $15.3 \%$ had adult education (table 2.) Equally, the result for the non-beneficiaries shows that majority (58.9\%) attended secondary school, while $16.1 \%$ had adult education $17.9 \%$ had primary education and $5.4 \%$ had no formal education. This implies that majority of the respondents attended one form of the formal education or the other. Similar Study by Balogun and Yusuf (2011). Also suggested that most of Fadama farmers (84.9\%) 
possessed primary, secondary or tertiary education.

Household Size- Household size is an important factor because it determines the consumption pattern and supply of labour in traditional agriculture. The result in table 2 reveals that $44.1 \%$ of the beneficiaries had an average household size of between 6 - 10. About 27.1\% had 11 - 16 household size, while (20.5\%) had 1-5 household size and 8.5\% had more than 17 household size. For the non- beneficiaries, about $42.9 \%$ had within $6-10,25 \%$ had within $1-5,19.6 \%$ had within $11-16$ and $12.5 \%$ had more than 17 household sizes. The implication of this is that the respondents had a fairly large household size which can be used as a source of farm labour.

\subsection{COST AND RETURNS OF THE RESPONDENTS}

The cost and returns analysis of rice production per hectare of farmland in Yola North Local Government Area of Adamawa state is contained in table 3 above. For the purpose of this study, the gross margin analysis and other profitability ratios were used to determine the profitability of rice production on 1 hectare farmland in the study area, comparing that of the Fadama III beneficiaries and the non beneficiaries. This is estimated by adding up the gross revenue less total variable cost. However, the study survey showed that total gross revenue of 0352,000 is generated from sales of rice per hectare for the non-beneficiaries and 0385,000 for the beneficiaries, showing a difference between them. The benefit cost ratio for the beneficiaries being 2.15 implies that for every $\mathrm{N} 1$ costs the farmers gets benefits of N2.15 while the nonbeneficiaries gets $\mathrm{N} 1.77$ for every $\mathrm{N} 1$ costs. The margin ratio was estimated to be 0.53 for the beneficiaries which implies that for every N1 generated in the sales of rice, the farmer has $\mathrm{N} 53$ to cover basic operating costs and profits while the non-beneficiaries gets N51 to cover basic operating costs and profits for every N1 generated in the sales of rice. Based on the research conducted on the objective, the revenue generated by the beneficiaries is higher than that of the non-beneficiaries. This correspond with the findings of Madu and Umar $(2011,2013)$, who reported that yields among the beneficiaries have increased significantly due to adoption of proven technologies.

\subsection{CHANGE IN FARM SIZE AND INCREASE IN OUTPUT}

The result in Table 5 shows that the mean farm size of the beneficiaries and non beneficiaries were 1.99 and 1.83 respectively. The mean difference between the beneficiaries and non-beneficiaries was statistically significant at $(p=0.05)$. This implies that beneficiaries appeared to have had relatively larger hectarage than non-beneficiaries. The reason for this differential farm size is as a result of support received from Fadama III project. On the other hand, the table reveals that the output of the beneficiaries were 36.28814 and 34.30357 respectively. There was no significant difference between the output of the beneficiaries and non-beneficiaries at $\mathrm{P}=0.05$ as a result of adoption of the beneficiaries at $\mathrm{P}=0.05$ as result of the adoption of the technologies induced by Fadama III project. This correspond with the findings of 


\begin{tabular}{|c|c|c|c|c|c|c|}
\hline & \multicolumn{2}{|c|}{$\begin{array}{l}\text { Benefi- } \\
\text { ciaries }\end{array}$} & \multicolumn{4}{|l|}{$\begin{array}{l}\text { Non - } \\
\text { Beneficia- } \\
\text { ries }\end{array}$} \\
\hline & Averag & & Values (N) & \multicolumn{2}{|c|}{ Average/Ha } & $\begin{array}{l}\text { Val- } \\
\text { ues } \\
(\mathrm{N})\end{array}$ \\
\hline Items & $\begin{array}{l}\text { quan- } \\
\text { tity }\end{array}$ & $\begin{array}{l}\text { unit } \\
\text { price/ } \\
\operatorname{cost}(\mathrm{N})\end{array}$ & & $\begin{array}{l}\text { quan- } \\
\text { tity }\end{array}$ & $\begin{array}{l}\text { unit } \\
\text { price/ } \\
\operatorname{cost}(\mathrm{N})\end{array}$ & \\
\hline \multicolumn{7}{|l|}{ Revenue: } \\
\hline $\begin{array}{l}\text { Paddy rice yield (output) } \\
\text { (kg) }\end{array}$ & 3500 & 110 & 385000 & 3200 & 110 & 352000 \\
\hline Total revenue(A)(N) & & & 385000 & & & 352000 \\
\hline \multicolumn{7}{|l|}{ Variable cost (input) } \\
\hline Rice seed(50kg/bag) & 70 & 290 & 20,300 & 70 & 360 & 25,200 \\
\hline Fertilizer(50kg/bag) & 8 & 5200 & 41,600 & 8 & 5700 & 45,600 \\
\hline $\begin{array}{l}\text { Agro-chemical (pre \& post } \\
\text { emergence) (L) }\end{array}$ & 14 & 2250 & 31,500 & 14 & 2400 & 33600 \\
\hline Bags (No) & 66 & 40 & 2,640 & 60 & 40 & 2400 \\
\hline $\begin{array}{l}\text { Labour cost Ploughing, } \\
\text { harrowing and levelling } \\
\text { (MD) }\end{array}$ & 3 & 2900 & 8700 & 3 & 3000 & 9000 \\
\hline Planting (MD) & 12 & 300 & 3600 & 12 & 300 & 3600 \\
\hline Fertilizer application (MD) & 10 & 1000 & 10,000 & 10 & 1000 & 10,000 \\
\hline $\begin{array}{l}\text { Weeding herbicide } \\
\text { application (MD) }\end{array}$ & 3 & 2000 & 6000 & 2 & 1500 & 3000 \\
\hline Harvesting/treshing (MD) & 5 & 11000 & 5000 & 4 & 10,000 & 40,000 \\
\hline Total Variable Cost (B) & & 179340 & & & & 172,400 \\
\hline Fixed Cost (Depreciation) & & negligible & & & & \\
\hline Rent on land & & & & & & 6400 \\
\hline Interest on loan & & & & & & 8000 \\
\hline $\begin{array}{l}\text { Depreciation on implement/ } \\
\text { machines used }\end{array}$ & & & & & & 12520 \\
\hline Total depreciation (C) & & & 0 & & & 27000 \\
\hline Total cost (D) & & & 179340 & & & 199,400 \\
\hline Gross margin $(A-B)=E$ & & & 205660 & & & 179600 \\
\hline Net returns $(\mathrm{E}-\mathrm{C})=\mathrm{F}$ & & & 205660 & & & 152600 \\
\hline Benefit/cost ratio (A/D) & & & 2.15 & & & 1.77 \\
\hline Gross margin ratio & & & 0.53 & & & 0.51 \\
\hline
\end{tabular}


Madu and Umar $(2011,2013)$, who reported that yields among the beneficiaries have increased significantly due to adoption of proven technologies introduced to them and that the project did not only influence the direct beneficiaries but also has influenced the non-beneficiaries living in Fadama III communities to adopt technologies.

Table 5 Change in Income

\begin{tabular}{ccccc}
\hline & Beneficiaries & $\begin{array}{c}\text { Non- } \\
\text { Beneficiaries }\end{array}$ & T-test & P-value \\
$\begin{array}{c}\text { Average income } \\
\text { before }\end{array}$ & 107633.9 & 1.83 & -1.218 & 0.2266 \\
$\begin{array}{c}\text { Average income } \\
\text { after }\end{array}$ & 142077.6 & 115457.6 & -1.2413 & 0.211 \\
\hline
\end{tabular}

Source: field work, 2019.

Change in Income- The result in table 3 shows that the mean annual income for the beneficiaries before the project was N 107, 633.9 compared to N 142, 077.6 after the project. This shows an increase in income of $\mathrm{N} 34,443.7$ as a result of participation in the Project. This agrees with the findings of World Bank (2001), which reported that many studies have shown an increase in the income of the beneficiaries as a result of participating in Fadama project. Further analysis (t-test) indicates, that there was no significant difference in income increase between the beneficiaries and nonbeneficiaries at $\mathrm{P}=0.05$. This may not be unconnected with the spill-over effect, as the non-beneficiaries might have benefited from the activities of the project.

\section{CONCLUSION AND RECOMMENDATION}

The findings revealed that beneficiaries had higher income than the nonbeneficiaries even though their means of income difference was not significant at $\mathrm{p}=0.05$. This indicates that the project has made a little positive impacts on the income of the beneficiaries in the study area. However, it was evident that the beneficiaries had adopted new technologies that were introduced by the project which has led to a significant increase in their output which found to be higher than that of the non-beneficiaries. Similarly the living condition of the beneficiaries had improved which showed in increased household assets, marrying more wives and increase in their nutritional intake which was significantly higher than the non-beneficiaries at $\mathrm{p}=0.05$. It can be concluded that the project has made a little positive impact on the livelihood of the beneficiaries in Yola north Local Government Area of Adamawa State, Nigeria.From the foregoing results, therefore it was recommended that; Fadama III and its activities should be left to continue in order to insure sustained income generation and better level of living among the rural farmers. Education is a key factor in reduction of rural poverty in general, whether the household are headed by men or women, therefore, should be encouraged among rural farmers. There should be improved extension program in the study area so that farmers can 
be educated on how to use new technologies in other to increase rate of adoption of new technologies among farmers and conclusively Fadama III beneficiaries should be encouraged to diversify their sources of income in order to increase their income status and livelihood.

\section{REFERENCES}

Adebayo, A. A. (1999). Adamawa State in maps, Geography Department, FUT, Yola and Paraclet publishers (Adebayo, A.A., Tukur, \& A. I., Eds.).

Akangbe, J. A., Ogunyinka, W., Ayanda, I. F., Achem, B., \& Adisa, R. S. (2012). An Assessment Of Effects of Fadama II Project On Livelihood of Farmers in Orire Local Government Area of Oyo State. Nigeria. Nigerian Journal of agriculture, Food and Environment, 8(1), 27-32.

Anambra State Agricultural Development Project. (2000).

Balogun, O. L., \& Yusuf, S. A. (2011). Effects of Social Capital on Welfare of Rural Households in South-Western States, 7, 506-514.

Bank, W. (2001). Nigeria National Fadama Development program II: Proposal for Project Development Fund (PDF). World Development Report.

Iwala, O. S. (2014). Economic impact, viability and sustainability of Fadama III small-scale community-owned infrastructure in Ondo State. Nigeria. American Journal of Research Communication, 2(5), 60-70.

Madu, A. U. (2013). The Adoption Rate of Technologies among Fadama III farmers in Adamawa State. Asian Journal of Agriculture and Rural Development, 3(9), 657-666.

National Population Commission. (2010). National Population Commission.

Obiechina, A., \& B, C. O. (2000). Increased Food Production and Alleviating Poverty Through Fadama Small scale Irrigated Farming in Anambra State. Awka (ADP) Nigeria Pp.

Oriola, E. O. (2009). A framework for food security and poverty reduction in Nigeria. European Journal of Social Sciences, 8(1).

The planning in upgrading of Rice Production in Kano State. (2007). Kano State Agricultural and Rural Development Authority, 1-1.

Umar, A. M., \& Mahmood, H. U. (2011). The Effect of Technology Adoption on Yields among Fadama III Farmers in Adamawa State. Nigeria. Taraba Journal of Agricultural Research. 